\title{
Plaque with Asymptomatic Verrucous Surface on the Right Leg: Dermatofibroma
}

Sağ bacakta asemptomatik verrüköz yüzeyli plak: Dermatofibrom

\section{İsa An ${ }^{1}$, Derya Uçmak ${ }^{1}$, İbrahim İbiloğlu ${ }^{2}$, Murat Öztürk ${ }^{3}$}

\begin{abstract}
Dermatofibroma is a benign fibrohistiocytic neoplasia. The etiology of dermatofibroma remains uncertain but it is considered to have a traumatic origin such as an insect bite or follicular rupture. Dermatofibroma clinically presents as smooth-surface nodular lesions. We report a patient with a plaque with asymptomatic verrucous surface on the right leg.

Keywords: dermatofibroma, verrucous, leg

Öz

Dermatofibrom sık görülen benign fibrohistiyositik bir neoplazidir. Etiyolojisi halen belirsizliğini korumaktadır fakat böcek 1sırması ve follikül rüptürü gibi bir travmadan kaynaklanabileceği kabul edilmektedir. Dermatofibrom klinikte genellikle düzgün yüzeyli nodüler lezyonlar şeklinde görülmektedir. Burada sağ bacakta asemptomatik verrüköz yüzeyli plağı olan bir hastayı sunuyoruz.
\end{abstract}

Anahtar sözcükler: Dermatofibrom, verrüköz, bacak
${ }^{1}$ Department of Dermatology, Dicle University Medical Faculty, Diyarbakır, Turkey ${ }^{2}$ Department of Pathology, Dicle University Medical Faculty, Diyarbakir, Turkey ${ }^{3}$ Department of Dermatology, Yuzuncu Yil University Medical Faculty, Van, Turkey

Informed Consent: The written consent was received from the patient who was presented in this study.

Hasta Onamı: Çalıșmada sunulan hastadan yazılı onam alınmıştır.

Conflict of Interest: No conflict of interest was declared by the authors.

Çıkar Çatışması: Yazarlar çıkar çatışması bildirmemişlerdir.

Financial Disclosure: The authors declared that this case has received no financial support.

Finansal Destek: Yazarlar bu olgu için finansal destek almadıklarını beyan etmişlerdir.

Geliş Tarihi / Received: 22.03.2018

Kabul Tarihi / Accepted: 04.05.2018

Yayın Tarihi / Published: 20.07.2018

Sorumlu yazar / Corresponding author: Isa An

Dicle University, Sur /Diyarbakır, Turkey

Phone: +90(412)2488001

Fax: +90(412)2488240

e-mail: is_an89@hotmail.com

Copyright $($ ACEM 


\section{Introduction}

Dermatofibroma (DF) is a commonly seen benign fibrohistiocytic neoplasia. Although it is mostly seen in adults and in the lower extremities, it can also affect any part of the body. There is a slight female predominance in DF [1]. DF clinically presents as smooth-surface nodular lesions [1]. on the leg.

We report a patient with plaque with verrucous surface

\section{Case report}

A thirty-year-old male patient presented to our clinic with a 3-year history of asymptomatic mass on the right leg. The patient had no systemic disease, drug use, and no history of trauma in the lesion site. Physical examination revealed a $3 \times 3 \mathrm{~cm}$ immobile, firm plaque with verrucous surface on the extensor surface of the right leg (Figure 1). No lesions were seen on the mucosal surfaces and the nails. Routine laboratory tests including complete blood count and liver function tests were normal. Histopathological evaluation showed a lesion with acanthosis on the epidermis, increased basal layer pigmentation, fibroblastic cell proliferation (Figure 2), and collagen foci entrapped by fibroblastic cells (Figure 3). In the immunohistochemical evaluation of the lesion was positive for factor XIIIa, vimentin, and muscle spesific actin and negative for S100 and CD34. Based on these findings, the patient was diagnosed with dermatofibroma. The lesion was excised completely with negative surgical margins.

Written consent was taken from the patient.

Figure 1: A $3 \times 3 \mathrm{~cm}$ immobile, firm, verrucous plaque seen on the extensor surface of the right leg.

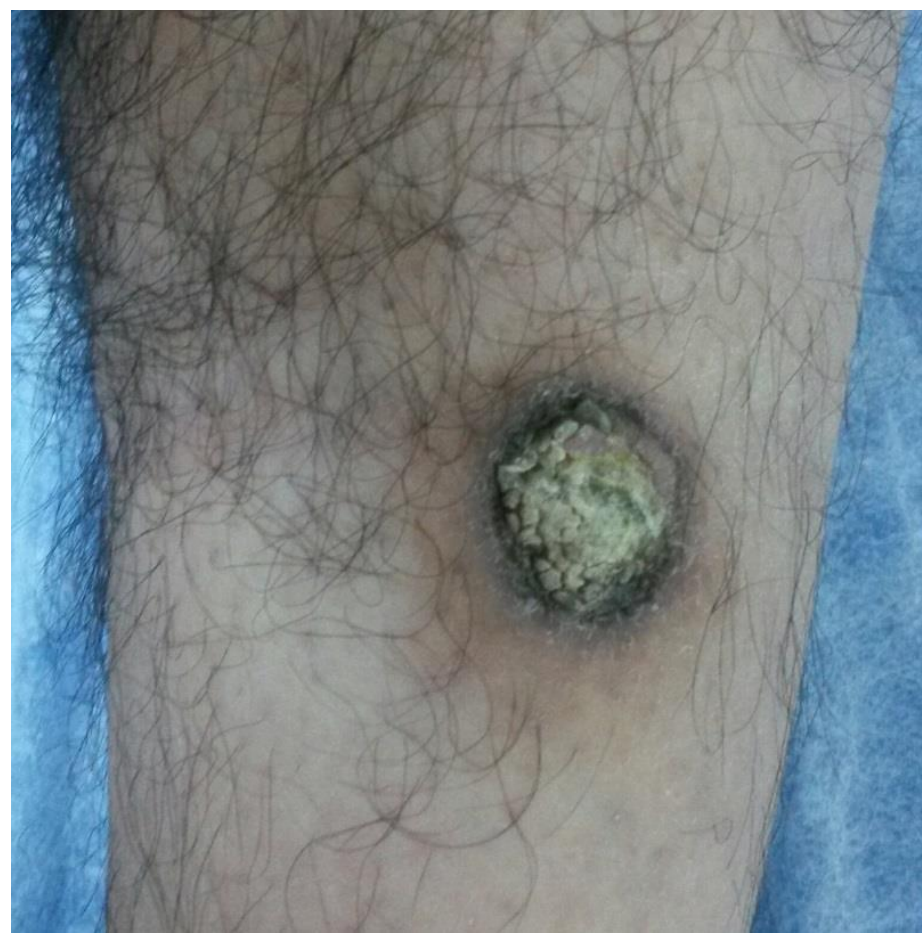

Figure 2: A lesion with acanthosis on the epidermis, increased basal layer pigmentation, and fibroblastic cell proliferation (H\&E, X40).

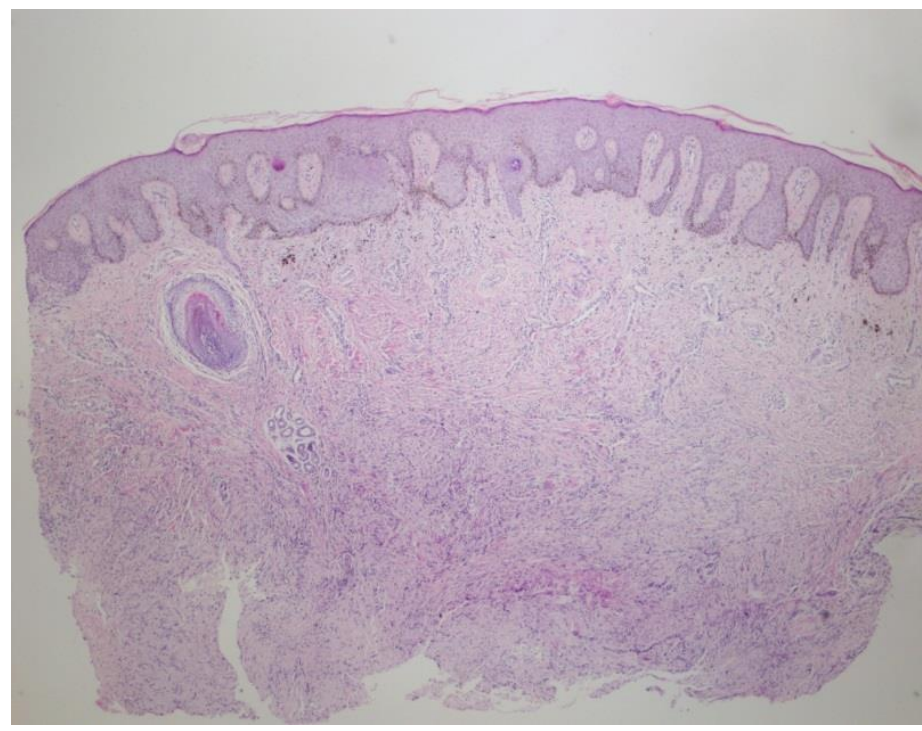

Figure 3: Collagen foci entrapped by fibroblastic cells (H\&E, X400).

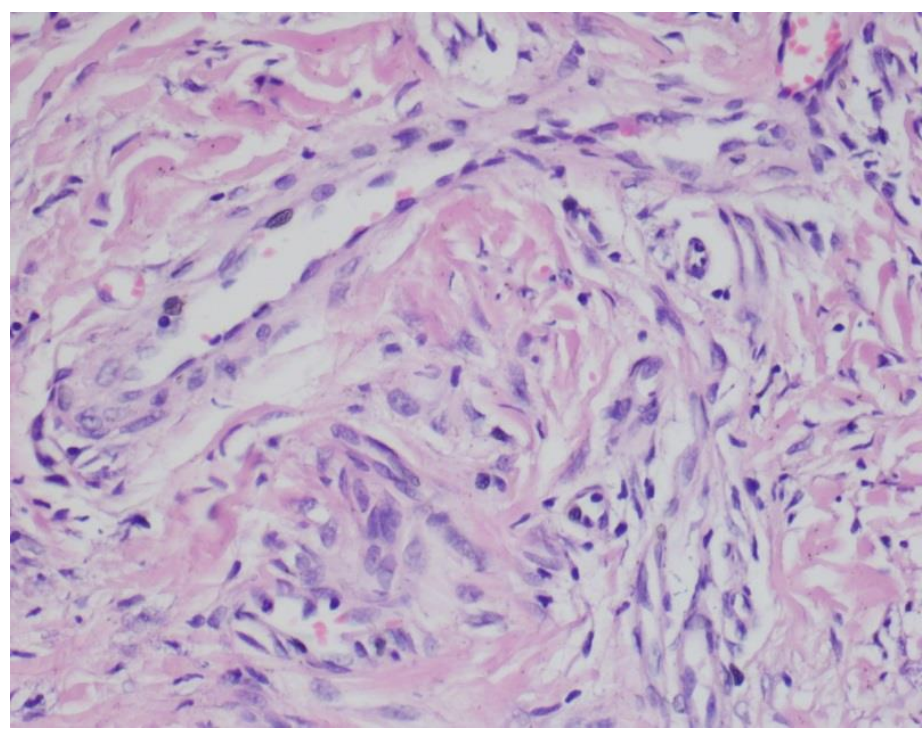

\section{Discussion}

DF commonly presents as firm, hyperkeratotic or domeshaped papules varying in size from a few millimeters to $1 \mathrm{~cm}$ and rarely reaching $2 \mathrm{~cm}$. While the lesions are usually hyperpigmented, they can vary from brown to pink in patients with low-pigmented skin [2]. Our patient was present with fleshcolored plaques with a verrucous surface. The lesions in dermatofibroma are usually solitary but 2-5 lesions can be seen in approximately $10 \%$ of the patients. In addition, rash and ulceration can also be seen, though rarely [3]. However, the lesion in our patient was asymptomatic.The etiology of DF remains uncertain but it is considered to have a traumatic origin such as an insect bite or follicular rupture [4]. Our patient did not have a trauma history. Multiple eruptive dermatofibromas have been reported in patients with systemic lupus erythematosus, human immunodeficiency virus, myasthenia gravis, mycosis fungoides, Sjogren's syndrome, pemphigus vulgaris, ulcerative colitis, and atopic dermatitis [1]. In DF, pressing the lesion with thumb and index finger causes a dimpled appearance on its surface and this helps in the differentiation of DF from other clinical conditions. Although the clinical diagnosis of DF is often easy to establish, it might be difficult to distinguish DF from 
dermatofibrosarcoma protuberans, granular cell tumors, clear cell acanthoma, and melanoma [2, 3].

Typical histopathological findings of DF include dense polymorphic infiltrate of lymphocytes, plasma cells, and histiocytes as well as dermal findings particularly including thick collagen bundles in the peripheral area and increased capillary density. These findings may also be accompanied by acanthosis, epidermal hyperplasia, interlocking retes, and increased basal layer pigmentation. In the immunohistochemical evaluation, DF is often positive for factor XIIIa, vimentin, and muscle specific actin and negative for S100 and CD34 [2,4].

The main histological types of DF are fibrocollagenous, cellular, histiocytic, lipidized, angiomatous, aneurysmal, clear cell, monster cell, myxoid, keloidal, palisading, osteoclastic and epithelioid dermatofibroma $[4,5]$. Our patient was diagnosed as having fibrocollagenous type of DF. In DF, spontaneous resolution can occur in some patients after a long follow-up period. However, malignant transformation of the lesions is not likely. In the patients with cosmetic concerns, the lesions can be totally excised [3]. Similarly, the lesion in our patient was excised completely.

Dermatofibroma clinically presents as smooth-surface nodular lesions. In our patient, the lesion had a verrucous surface. Clinicians should keep dermatofibroma in mind particularly in the diagnosis of the patients presenting with verrucose lesions on the legs.

\section{References}

1. Enzinger FM, Weiss SW. Benign fibrohistiocytic tumours. Soft Tissue Tumours.3rd ed. St Louis: Mosby; 1995. pp. 293-303.

2. Han TY, Chang HS, Lee JH, Lee WM, Son SJ. A clinical and histopathological study of 122 cases of dermatofibroma (benign fibrous histiocytoma). Ann Dermatol. 2011;23:185-92.

3. Ahn SK, Lee NH, Kang YC, Choi EH, Hwang SM, Lee SH. Histopathologic and immunohistochemical findings of dermatofibromas according to the clinical features and duration. Korean J Dermatol. 2000;38:500-5.

4. Şenel E, Yuyucu Karabulut Y, Doğruer Şenel S. Clinical, histopathological, dermatoscopic and digital microscopic features of dermatofibroma: a retrospective analysis of 200 lesions. J Eur Acad Dermatol Venereol. 2015;29:1958-66.

5. Alves JV, Matos DM, Barreiros HF, Bartolo EA. Variants of dermatofibroma - a histopathological study. An Bras Dermatol. 2014;89:472-7. 